Article

\title{
Pharmacokinetics of Selected Anticancer Drugs in Elderly Cancer Patients: Focus on Breast Cancer
}

\author{
Marie-Rose B.S. Crombag ${ }^{1,2}$, Markus Joerger ${ }^{3, *}$, Beat Thürlimann ${ }^{4}$, Jan H.M. Schellens ${ }^{2,5,6}$, \\ Jos H. Beijnen ${ }^{1,2,5}$ and Alwin D.R. Huitema $1,2, *$
}

Received: 16 September 2015; Accepted: 29 December 2015; Published: 2 January 2016

Academic Editor: Jonas Cicènas

1 Department of Pharmacy \& Pharmacology, The Netherlands Cancer Institute/Slotervaart Hospital, Amsterdam 1066 CX, The Netherlands; marie-rose.crombag@slz.nl (M.-R.B.S.C.); jos.beijnen@slz.nl (J.H.B.)

2 Department of Clinical Pharmacology, The Netherlands Cancer Institute, Amsterdam 1066 CX, The Netherlands; j.schellens@nki.nl

3 Department of Medical Oncology, Cantonal Hospital, St. Gallen 9007, Switzerland

4 Breast Center, Cantonal Hospital, St. Gallen 9007, Switzerland; beat.thuerlimann@kssg.ch

5 Department of Pharmaceutical Sciences, Division of Pharmacoepidemiology \& Clinical Pharmacology, Utrecht University, Utrecht 3508 TC, The Netherlands

6 Department of Medical Oncology, The Netherlands Cancer Institute, Amsterdam 1066 CX, The Netherlands

* Correspondence: markus.joerger@kssg.ch; alwin.huitema@slz.nl

\begin{abstract}
Background: Elderly patients receiving anticancer drugs may have an increased risk to develop treatment-related toxicities compared to their younger peers. However, a potential pharmacokinetic (PK) basis for this increased risk has not consistently been established yet. Therefore, the objective of this study was to systematically review the influence of age on the PK of anticancer agents frequently administered to elderly breast cancer patients. Methods: A literature search was performed using the PubMed electronic database, Summary of Product Characteristics (SmPC) and available drug approval reviews, as published by EMA and FDA. Publications that describe age-related PK profiles of selected anticancer drugs against breast cancer, excluding endocrine compounds, were selected and included. Results: This review presents an overview of the available data that describe the influence of increasing age on the PK of selected anticancer drugs used for the treatment of breast cancer. Conclusions: Selected published data revealed differences in the effect and magnitude of increasing age on the PK of several anticancer drugs. There may be clinically-relevant, age-related PK differences for anthracyclines and platina agents. In the majority of cases, age is not a good surrogate marker for anticancer drug PK, and the physiological state of the individual patient may better be approached by looking at organ function, Charlson Comorbidity Score or geriatric functional assessment.
\end{abstract}

Keywords: pharmacology; pharmacokinetics; anticancer drugs; elderly; breast cancer

\section{Introduction}

The majority of patients diagnosed with cancer are aged 65 years and older, and it is predicted that in the period from 2010-2030, the cancer incidence in the elderly will increase by 67\% [1]. Elderly patients (often defined as $\geqslant 65$ years of age) are routinely treated with anticancer drugs; however, the pharmacokinetics and pharmacodynamics (PK and PD) of these agents have not been thoroughly investigated in this population thus far. Despite the increasing size of the geriatric population and specific guidance on studies in geriatrics [2], the elderly patient is mostly excluded from clinical trials due to short life expectancy, performance status, comorbidities and/or comedication [3,4]. In clinical trials, the underrepresentation of older patients has been substantial, even in cancer types that predominantly occur in the elderly [5-7]. FDA and EMA consider dose- and concentration-response 
information to be key for determining the safety and effectiveness of drugs [8,9]. Identification of the appropriate dosage regimen of an anticancer drug for the respective target population, including elderly patients, is crucial to ensure its safety and effectiveness in clinical practice.

In daily practice, elderly breast cancer patients have a higher risk of death from breast cancer compared to their younger peers [10]. This may be ascribed to a combination of factors, including tumor biology, patient characteristics and deviating treatment regimens applied in this population. Treatment strategies in elderly patients are often less stringent, and there is a general risk of undertreatment in elderly patients [10]. Elderly patients receiving anticancer drugs may have an increased risk to develop treatment-related toxicities compared to their younger peers. However, a potential PK basis for this increased risk has not consistently been established yet. Therefore, this review was designed to: (1) briefly outline the influence of aging on selected anticancer drug PK; and (2) describe the PK basis for potential dose adjustments of anticancer agents frequently administered to elderly breast cancer patients.

\section{Influence of Aging on Drug Pharmacokinetics}

With increasing age, multiple physiological parameters alter, which may substantially influence the PK of anticancer drugs. In elderly patients, the PK profile can be influenced by altered distribution, metabolism and elimination parameters, while changes in absorption rarely led to clinically-relevant differences, as depicted in Table 1 [11-14]. Changes in gastric $\mathrm{pH}$ may have variable impacts on anticancer drug absorption, while absorption of Class II oral therapeutic drugs, including tyrosine kinase inhibitors and endocrine agents, increases with increasing gastric $\mathrm{pH}$. Another typical example includes capecitabine, with a higher absorption in elderly patients with a higher gastric $\mathrm{pH}$, similar to increased absorption in the fed compared to the fasted state.

Table 1. Influence of aging on pharmacokinetics (PK) parameters.

\begin{tabular}{|c|c|c|c|}
\hline & Parameter & Direction & Effect on Exposure \\
\hline \multirow{5}{*}{ Absorption [11,13] } & Gastrointestinal pH & $\uparrow$ & $\downarrow \uparrow$ \\
\hline & Gastric emptying time & $\uparrow$ & $\downarrow$ \\
\hline & Motility & $\downarrow$ & $\downarrow$ \\
\hline & Splanchnic blood flow & $\downarrow$ & $\downarrow$ \\
\hline & Absorptive surface & $\downarrow$ & $\downarrow$ \\
\hline \multirow{10}{*}{ Distribution [11,13] } & Body composition & & \\
\hline & Body fat & $\uparrow$ & $\uparrow *$ \\
\hline & Plasma volume & $\downarrow$ & $\uparrow \S$ \\
\hline & Total body water & $\downarrow$ & $\uparrow \S$ \\
\hline & Intra-/extracellular body fluid & $\downarrow$ & $\uparrow \S$ \\
\hline & Plasma proteins & & \\
\hline & Serum albumin & $\downarrow$ & $\uparrow \mathrm{FF}$ \\
\hline & Bilirubin & $\downarrow$ & $\uparrow \mathrm{FF}$ \\
\hline & Erythrocytes & $\downarrow$ & $\uparrow \mathrm{FF}$ \\
\hline & Serum $\alpha 1$-acid glycoprotein & $\uparrow$ & $\downarrow \mathrm{FF}$ \\
\hline \multirow{3}{*}{ Metabolism [12] } & Hepatic blood flow & $\downarrow$ & $\uparrow$ \\
\hline & Hepatic mass & $\downarrow$ & $\uparrow$ \\
\hline & CYP P450 enzymes & $0 / \downarrow$ & $(\uparrow)$ \\
\hline \multirow{2}{*}{ Elimination $[11,13]$} & Renal blood flow / glomerular & $\downarrow$ & $\uparrow$ \\
\hline & Tubular secretion & $\downarrow$ & $\uparrow$ \\
\hline
\end{tabular}

* For lipophilic drugs; § for hydrophilic drugs; FF = free fraction.

These multifactorial and complex changes make it difficult to predict the net effect of aging on the PK profile of a specific drug administered to elderly breast cancer patients. Besides these physiological changes, multiple other factors contribute to the complexity of anticancer drug treatment in the elderly patient. Firstly, elderly patients often have several comorbidities and receive comedication that may negatively affect anticancer treatment $[12,15,16]$. For instance, patients with diabetes mellitus 
encountered more chemotherapy-related toxicities when receiving adjuvant chemotherapy for breast cancer compared to the non-diabetic control group [17]. While the exact reasons for this effect are unclear, a higher fat proportion in the elderly patient may result in impaired anticancer drug disposition and increased toxicity from various chemotherapy regimens. Furthermore, comorbidities were determined to significantly influence mortality rates in elderly patients diagnosed with cancer, regardless of the stage of disease at diagnosis [18,19].

Frailty, decreased mobility and impaired performance status may come with aging, although there is a large interindividual variability in the extent and rate of these processes. These factors are important parameters that help differentiate between geriatric and non-geriatric patients. Because the proportion and absolute number of elderly cancer patients is steadily increasing, and with it the detrimental impact of suboptimal cancer treatment, it is important to have adequate evidence-based anticancer drug regimens that are tailored to use in elderly breast cancer patients.

\section{Methodology}

A literature search was performed using the PubMed electronic database to identify available PK data on anticancer drugs that were frequently administered to elderly breast cancer patients, excluding endocrine compounds. The following keywords were used: pharmaco-kinetic; kinetic; PK; AUC; concentration; Cmax; half-life; in conjunction with aged, elderly, geriatric, ageing, aging, older, old people, frail elderly; which was subsequently combined with each anticancer agent included in this review, both by its generic and brand name. Results were limited to publications in humans, written in English, which were published through January 2015. Furthermore, the Summary of Product Characteristics (SmPC) and available drug approval reviews, as published by EMA and FDA, were analyzed to evaluate additional PK information. Publications that describe age-related PK profiles of all anticancer drugs included in this review were selected and included. Cited references were hand-searched and included when the set inclusion criteria were met.

\section{Results}

Table 2 depicts all studies investigating the influence of increasing age on the PK of anticancer drugs included in this review.

\subsection{Taxanes}

\subsubsection{Docetaxel}

Docetaxel is a highly lipophilic taxane anticancer drug that is $>94 \%$ bound to plasma proteins $[20,21]$. Altered distribution of docetaxel can be expected in the elderly patient who has an altered body composition and increased serum $\alpha 1$-acid glycoprotein [11,12]. With only a small fraction excreted renally, docetaxel undergoes hepatic metabolism by CYP3A4 into inactive metabolites and mainly undergoes biliary excretion $[21,22]$. The activity of CYP3A4 may be preserved with aging, although there is some controversy on this topic $[11,23,24]$. The number of older patients included in several trials was insufficient to determine differences in PK and PD related to age. For this reason, no evaluation of pivotal trial data has been conducted for elderly breast cancer patients [20]. Four different studies found no significant PK differences in elderly patients ( $n=50, n=54, n=40$ and $n=19$, respectively) compared to younger patients [25-28]. It should be noted that the latter study lacked a control group, including only patients aged 65 years or older [28]. On the contrary, two other studies ( $n=29$ and $n=20$, respectively) documented a significant decrease in docetaxel clearance with increasing age $[29,30]$. A subsequent larger study $(n=601)$ supported this significant effect of aging on docetaxel PK, although the observed decrease in clearance of $7 \%$ is not usually seen as clinically relevant [31]. Although apparently not PK-driven, a significant increase in (hemato-)toxicity was observed in various studies [25,27,28,31], supporting FDA's statement for cautious dose selection in elderly patients [20]. Nonetheless, in EMA's SmPC, it was stated that, based on population PK analysis [32], dose reductions in elderly patients are not recommended [33]. 
Table 2. Overview of studies assessing the pharmacokinetics of anticancer drugs in elderly patients.

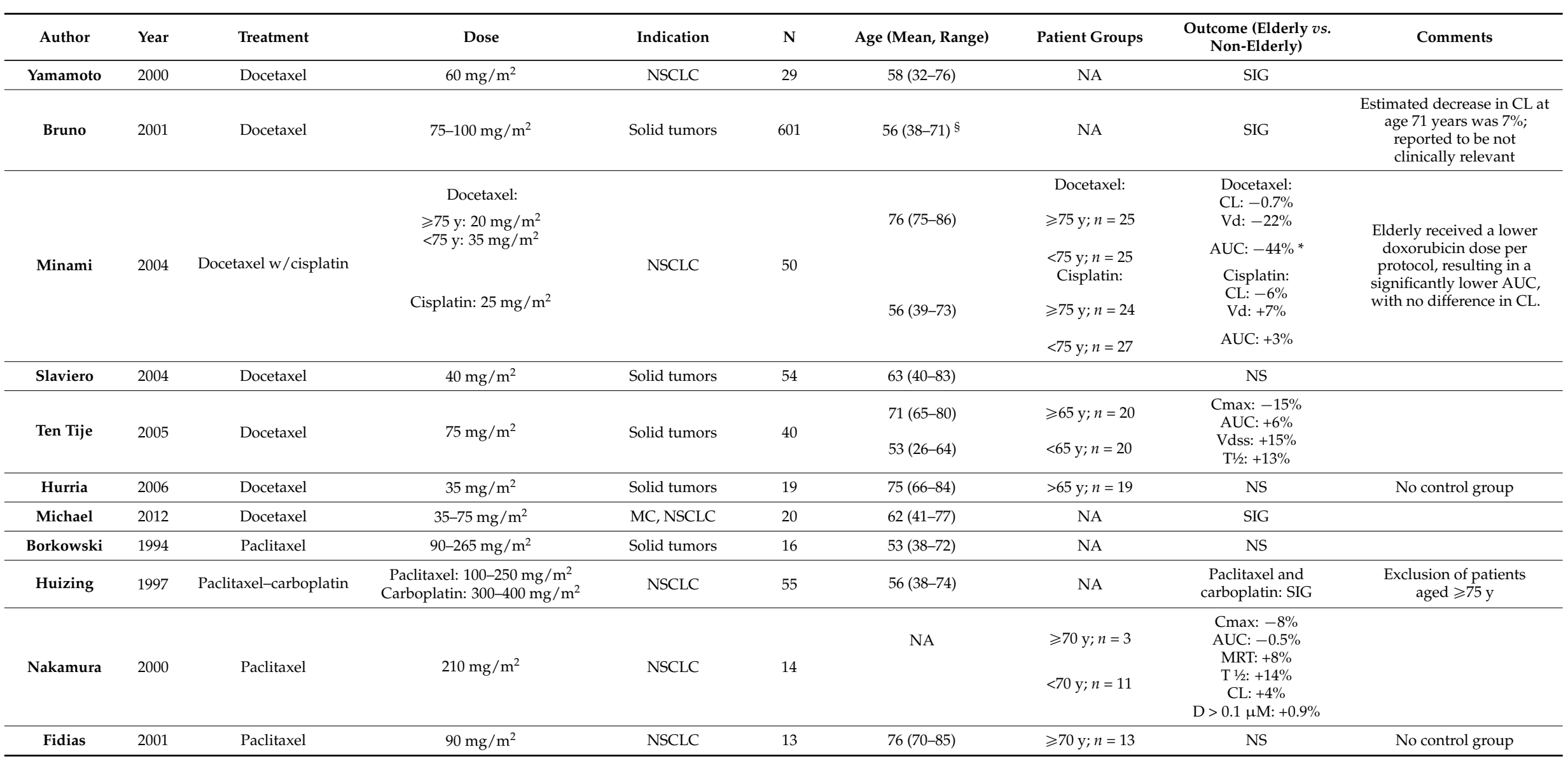


Table 2. Cont

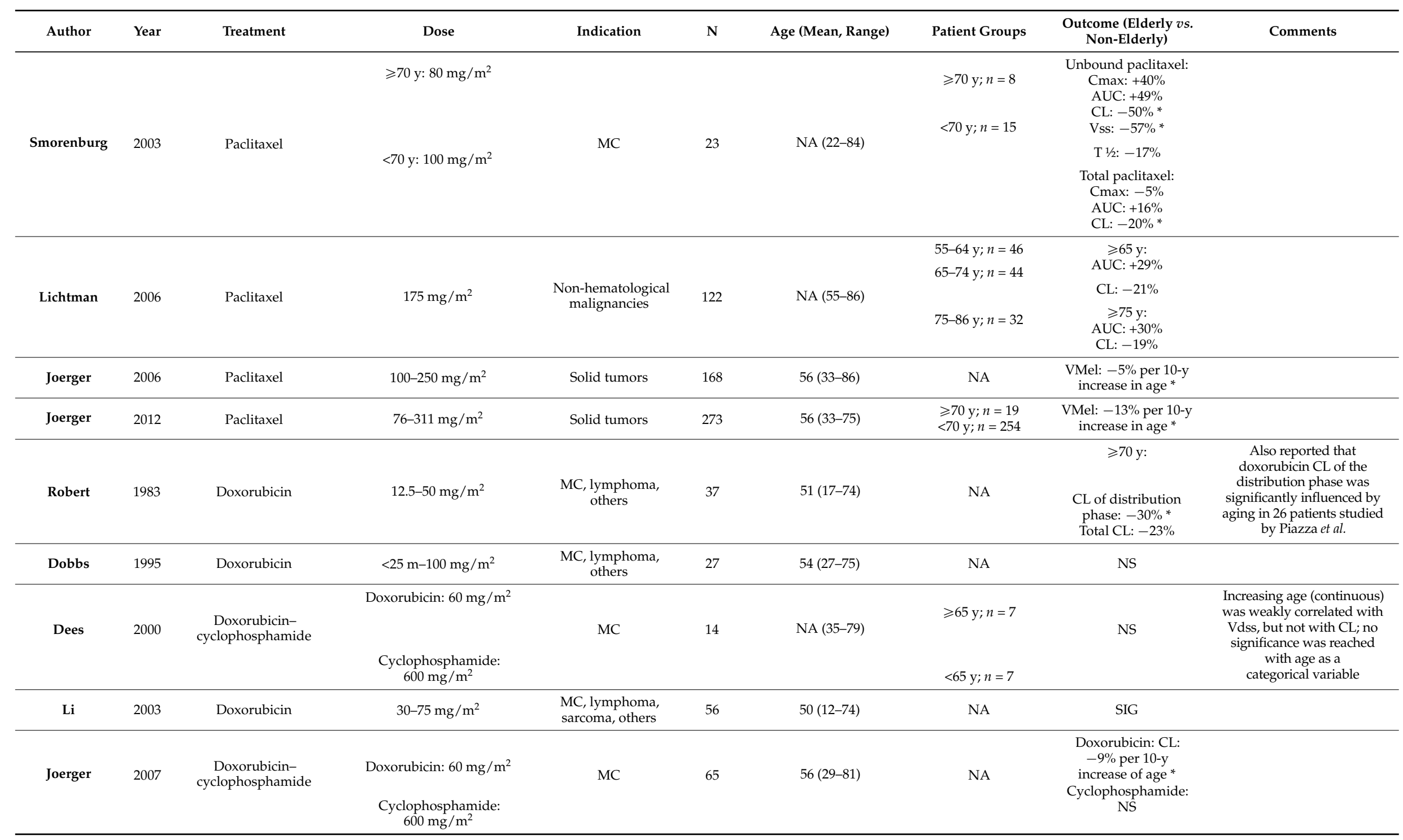


Table 2. Cont

\begin{tabular}{|c|c|c|c|c|c|c|c|c|c|}
\hline Author & Year & Treatment & Dose & Indication & $\mathrm{N}$ & Age (Mean, Range) & Patient Groups & $\begin{array}{l}\text { Outcome (Elderly vs. } \\
\text { Non-Elderly) }\end{array}$ & Comments \\
\hline Jakobsen & 1991 & Epirubicin & $40-135 \mathrm{mg} / \mathrm{m}^{2}$ & MC & 78 & NA (31-74) & NA & NS & \\
\hline Wade & 1992 & Epirubicin & $25-100 \mathrm{mg} / \mathrm{m}^{2}$ & $\begin{array}{l}\text { MC, lymphoma, } \\
\text { sarcoma }\end{array}$ & 36 & NA (20-73) & $\begin{array}{l}\geqslant 70 \mathrm{y} ; n=1 \\
<70 \mathrm{y} ; n=35\end{array}$ & SIG & $\begin{array}{l}\text { Significant in women only, } \\
\text { no elderly men } \\
\text { were included. } \\
\text { Predicted CL: - } 34 \% \\
\text { (70 vs. } 25 \text { y) } \\
\end{array}$ \\
\hline Eksborg & 1992 & Epirubicin & $60 \mathrm{mg} / \mathrm{m}^{2}$ & MC & 66 & 61 (36-78) & NA & SIG & \\
\hline Sorio & 1997 & Vinorelbine (iv) & $30 \mathrm{mg} / \mathrm{m}^{2}$ & $\mathrm{MC}$ & 10 & 72 (66-81) & $\geqslant 66 \mathrm{y} ; n=10$ & NS & No control group \\
\hline Gauvin & 2000 & Vinorelbine (iv) & $20-30 \mathrm{mg} / \mathrm{m}^{2}$ & Solid tumors & 12 & $74(66-79)$ & $\geqslant 66 \mathrm{y} ; n=12$ & SIG & No control group \\
\hline Gauvin & 2002 & Vinorelbine (iv) & $20-30 \mathrm{mg} / \mathrm{m}^{2}$ & Solid tumors & 27 & NA (66-79) & $\geqslant 66 \mathrm{y} ; n=27$ & SIG & $\begin{array}{l}\text { No control group } \\
\text { ECOG 0-3 }\end{array}$ \\
\hline Variol & 2002 & Vinorelbine (iv/po) & $\begin{array}{l}\text { Vinorelbine (iv): } \\
20-45 \mathrm{mg} / \mathrm{m}^{2} \\
\text { Vinorelbine (po): } \\
60-100 \mathrm{mg} / \mathrm{m}^{2}\end{array}$ & Solid tumors & $\begin{array}{l}\text { iv: } 64 \\
\text { po: } 175\end{array}$ & $\begin{array}{l}\text { iv: } 55(27-72) \\
\text { po: } 57(21-77)\end{array}$ & NA & NS & $\begin{array}{l}\text { iv same as Nguyen: } \\
3 \text { phase I studies }\end{array}$ \\
\hline Nguyen & 2002 & Vinorelbine (iv) & $20-45 \mathrm{mg} / \mathrm{m}^{2}$ & Solid tumors & 64 & $55(27-73)$ & NA & NS & 3 phase I studies \\
\hline Lush & 2005 & Vinorelbine (iv) & $30 \mathrm{mg} / \mathrm{m}^{2}$ & Solid tumors & 20 & $57(40-74)$ & $\begin{array}{l}\geqslant 65 \mathrm{y} ; n=14 \\
<65 \mathrm{y} ; n=6\end{array}$ & $\begin{array}{c}\text { Cmax: }+26 \% \\
\text { T } 1 / 2:+6 \% \\
\text { AUC: }+30 \% \\
\text { CL: }-17 \%\end{array}$ & $\begin{array}{l}\text { Age mean (range) for total } \\
\text { group of } 27 \text { pts, of which } \\
20 \text { received iv vinorelbine }\end{array}$ \\
\hline Wong & 2006 & Vinorelbine (iv) & Flat dose: $60 \mathrm{mg}$ & Solid tumors & 34 & $63(43-81)$ & NA & NS & $\begin{array}{l}\text { Age mean (range) for total } \\
\text { group of } 43 \text { pts, of which } \\
34 \text { pts were included for } \\
\text { PK analysis }\end{array}$ \\
\hline Puozzo & 2004 & Vinorelbine (po) & $60 \mathrm{mg} / \mathrm{m}^{2}$ & Solid tumors & 48 & $74(70-82)$ & $\begin{array}{c}\geqslant 70 \mathrm{y} ; n=48 \\
\text { Phase I }<70 \mathrm{y} \\
\text { population: } 56 \\
(31-82) ; n=52\end{array}$ & $\begin{array}{c}\text { AUC: }+11 \% \\
\text { Cmax: }+10 \% \\
\text { CL: }-2 \% \\
\text { T } 1 / 2:+7 \%\end{array}$ & $\begin{array}{l}\text { Phase II including elderly } \\
\text { compared w/phase I } \\
\text { reference population; same } \\
\text { population as Gridelli et al. }\end{array}$ \\
\hline Gridelli & 2006 & Vinorelbine (po) & $\begin{array}{c}60 \mathrm{mg} / \mathrm{m}^{2}, \text { after } 3 \text { cycles: } \\
80 \mathrm{mg} / \mathrm{m}^{2}\end{array}$ & NSCLC & 48 & $74(70-82)^{*}$ & $\geqslant 70 \mathrm{y} ; n=48$ & NS & $\begin{array}{l}\text { No control group; age } \\
\text { mean (range) for total } \\
\text { group of } 56 \text { patients, of } \\
\text { which } 48 \text { pts were included } \\
\text { for PK analysis (not } \\
\text { mentioned in Puozzo et al.) }\end{array}$ \\
\hline Port & 1991 & 5-FU & $320-960 \mathrm{mg} / \mathrm{m}^{2}$ & Solid tumors & 26 & $53(43-75)$ & NA & $\begin{array}{l}\text { CL: }-16 \% \\
(70 \text { y vs. } 50 \text { y) }\end{array}$ & \\
\hline Milano & 1992 & $5-\mathrm{FU}$ & $365-1224 \mathrm{mg} / \mathrm{m}^{2}$ & $\begin{array}{l}\text { Squamous cell } \\
\text { carcinoma of head } \\
\text { and neck }\end{array}$ & 360 & $62(25-91)$ & $\begin{aligned}>70 \text { y: } n & =58 \\
51-70 \text { y: } n & =245 \\
\leqslant 50 \text { y: } n & =57\end{aligned}$ & NS & $\begin{array}{l}\text { Only } 5 \text { elderly women } \\
\text { included }\end{array}$ \\
\hline Denham & 1999 & 5-FU-cisplatin & $\begin{array}{l}\text { 5-FU: } 800 \mathrm{mg} / \mathrm{m}^{2} \\
\text { Cisplatin: } 80 \mathrm{mg} / \mathrm{m}^{2}\end{array}$ & Esophageal cancer & 44 & $72(42-91)$ & NA & 5FU: SIG & \\
\hline
\end{tabular}


Table 2. Cont.

\begin{tabular}{|c|c|c|c|c|c|c|c|c|c|}
\hline Author & Year & Treatment & Dose & Indication & $\mathbf{N}$ & Age (Mean, Range) & Patient Groups & $\begin{array}{l}\text { Outcome (Elderly } v s . \\
\text { Non-Elderly) }\end{array}$ & Comments \\
\hline Duffour & 2010 & $5-\mathrm{FU}$ & NA & CRC & 103 & $\begin{array}{l}\geqslant 65 \text { y: } 70(65-80) \\
<65 \text { y: } 59(33-64)\end{array}$ & $\begin{array}{l}\geqslant 65 \mathrm{y}: n=48 \\
<65 \mathrm{y}: n=55\end{array}$ & $\begin{array}{c}\text { Cycle 1: } \\
\text { CL: }-3 \% \\
\text { Vd: }-8 \% \\
\text { T } 1 / 2:-4 \% \\
\text { AUC: } 0.5 \% \\
\text { Cycle 2: } \\
\text { AUC: } 10 \% \\
\end{array}$ & \\
\hline Mueller & 2013 & 5-FU & $\begin{array}{c}400 \mathrm{mg} / \mathrm{m}^{2} \text { bolus, followed } \\
\text { by } 2400 \mathrm{mg} / \mathrm{m}^{2 * *}\end{array}$ & Solid tumors & 31 & $63(31-81)$ & $\begin{array}{l}\geqslant 65 \text { y: } n=14 \\
<65 \text { y: } n=17\end{array}$ & NS & \\
\hline Cassidy & 1999 & Capecitabine & Flat dose: $2000 \mathrm{mg}$ & Solid tumors & 25 & $63(41-80)$ & NA & NS & $\begin{array}{l}\text { Bioequivalence study of } \\
\text { two tablet formulations }\end{array}$ \\
\hline Louie & 2013 & Capecitabine & $1000 \mathrm{mg} / \mathrm{m}^{2}$ & CRC & 29 & $\begin{array}{l}\geqslant 70 \text { y: } 77 \pm 5 \\
<60 \text { y: } 55 \pm 3\end{array}$ & $\begin{array}{l}\geqslant 70 \text { y: } n=24 \\
<60 \text { y: } n=5\end{array}$ & $\begin{array}{c}\text { Capecitabine: } \\
\text { Cmax: }+200 \% * \\
\text { T12: }+5 \% \\
\text { AUC: }+150 \% * \\
\text { CL: }-71 \%{ }^{*} \\
\text { Vd: }-74 \% * \\
\text { 5-FU: } \\
\text { Cmaa: }-23 \% \\
\text { T112:- }-10 \% \\
\text { AUC: }-26 \%\end{array}$ & \\
\hline Daher Abdi & 2014 & Capecitabine & $1250-2300 \mathrm{mg} / \mathrm{m}^{2}$ & $\mathrm{MC}, \mathrm{CRC}$ & $20+40$ & $\begin{array}{l}\geqslant 75 \text { y: } 81(75-92) \\
<75 \text { y: } 55(30-73)\end{array}$ & $\begin{array}{l}\geqslant 70 \text { y: } n=20 \\
<75 \text { y: } n=40\end{array}$ & NS & $\begin{array}{l}\text { PK data of } 40 \text { patients }<75 \mathrm{y} \\
\text { from } 2 \text { previous } \\
\text { phase I trials }\end{array}$ \\
\hline Merino-Sanjuan & 2011 & Carboplatin-gemcitabine & $\begin{array}{l}\text { Carboplatin: } \\
\geqslant 70 \text { y: AUC } 4 \text { vs. } \\
<70 \text { y: AUC } 5\end{array}$ & NSCLC & 24 & $\begin{array}{l}\geqslant 70 \text { y: } 77(71-81) \\
<70 \text { y: } 58(44-66)^{\S}\end{array}$ & NA & $\begin{array}{l}\text { Carboplatin: CL: } \\
-31 \% *\end{array}$ & $\begin{array}{l}\text { Age mean (range) for total } \\
\text { group of } 33 \text { pts, of which } \\
24 \text { pts were included for } \\
\text { PK analysis }\end{array}$ \\
\hline Yamamoto & 1995 & Cisplatin & $80 \mathrm{mg} / \mathrm{m}^{2}$ & NSCLC & 23 & $61(41-81)$ & $\begin{array}{l}>70 \text { y: } n=8 \\
\leqslant 70 \text { y: } n=15\end{array}$ & SIG & \\
\hline Gupta & 2012 & $\begin{array}{l}\text { Trastuzumab } \\
\text { emtansine }\end{array}$ & $1.2-4.8 \mathrm{mg} / \mathrm{kg}$ & MC & 273 & 54 (SD 10 y) & NA & NS & $\begin{array}{c}87 \% \text { of pts received } \\
3.6 \mathrm{mg} / \mathrm{kg}\end{array}$ \\
\hline $\mathrm{Lu}$ & 2014 & $\begin{array}{l}\text { Trastuzumab } \\
\text { emtansine }\end{array}$ & $1.2-4.8 \mathrm{mg} / \mathrm{kg}$ & MC & 671 & $53(27-84)$ & $\begin{array}{c}>75 \mathrm{y}: n=16 \\
65-75 \mathrm{y} ; n=78 \\
<65 \mathrm{y} ; n=577\end{array}$ & NS & $\begin{array}{c}95 \% \text { of pts received } \\
3.6 \mathrm{mg} / \mathrm{kg}\end{array}$ \\
\hline Motzer & 2008 & Everolimus & Flat dose: $10 \mathrm{mg} /$ day & RCC & 272 & $61(27-85)$ & NA & NS & $\begin{array}{l}\text { As reported in the FDA's } \\
\text { drug approval review }\end{array}$ \\
\hline
\end{tabular}

* Significant effect, as defined in the original publication; $§$ age median/mean (range) concerns total group of included patients in the study, of which only a part was included for PK analysis of the specific administrated treatment drug; ** as simulated using NONMEM, whereas the actual dosing range was not provided, yet was given as part of FOLFOX, FOLFIRI 5-fluorouracil (5-FU) or FOLFIRINOX; NS = non-significant influence of aging on PK parameters, as displayed when the percentage of change of PK parameters could not be ascertained from the article, e.g., when results were presented using population PK modeling; $N=$ patient number; $S I G=$ significant influence of aging on PK parameters, as displayed when the percentage of change of PK parameters could not be ascertained from the article, e.g., when results were presented using population PK modeling; AUC = area under the concentration-time curve $(\mu \mathrm{g} / \mathrm{mL} \cdot \mathrm{h}, \mu \mathrm{g} / \mathrm{mL} \cdot \mathrm{min}, \mu \mathrm{g} / \mathrm{L} \cdot \mathrm{h}$ or $\mu \mathrm{mol} / \mathrm{L} \cdot \mathrm{h}) ; \mathrm{C} \max =$ maximum plasma concentration $(\mu \mathrm{g} / \mathrm{mL}$ or $\mu \mathrm{g} / \mathrm{L}) ; \mathrm{CL}=$ clearance $(\mathrm{L} / \mathrm{h}, \mathrm{L} / \mathrm{min}, \mathrm{mL} / \mathrm{min}$ or L/h/m2); Vss = volume of distribution at steady-state conditions; $\mathrm{CRC}=$ colorectal cancer; $\mathrm{D}>0.1 \mu \mathrm{M}=$ duration drug concentration above $0.1 \mu \mathrm{M}(\mathrm{h}) ; \mathrm{ECOG}=$ Eastern Cooperative Oncology Group score; FDA = Food and Drug Administration; iv = intravenous; $\mathrm{MC}=$ mamma carcinoma; $\mathrm{MRT}=$ mean residence time $(\mathrm{h}) ; \mathrm{NSCLC}=$ non-small cell lung cancer; $\mathrm{PK}=$ pharmacokinetics; po = per os; RCC = renal cell carcinoma; $\mathrm{SD}=$ standard deviation; $\mathrm{T}^{1} 12 \mathrm{2}=$ terminal half-life ( $\mathrm{h}$ or $\left.\mathrm{min}\right) ; \mathrm{Vd}=$ volume of distribution $(\mathrm{L}) ; \mathrm{Vdss}=$ volume of distribution at steady state $(\mathrm{L}$, or $\mathrm{L} / \mathrm{m} 2)$; $\mathrm{VMel}=\mathrm{maximal}$ elimination capacity $(\mu \mathrm{mol} / \mathrm{h}) ; \mathrm{y}=$ year 


\subsubsection{Paclitaxel}

Paclitaxel is highly plasma protein bound, with a large apparent volume of distribution. It is extensively metabolized in the liver by CYP3A4 and, to a lesser extent, by CYP2C8, into inactive metabolites [34]. Paclitaxel showed a high inter- and intra-patient PK variability [35]. A retrospective small Japanese study $(n=14)$ showed no PK differences with increasing age [36]. Two prospective small studies ( $n=13$, and $n=16$, respectively) supported this similar PK profile $[37,38]$. However, one of these studies lacked a control group [37]. On the contrary, in another study $(n=23)$, increasing age was inversely associated with paclitaxel elimination, showing a $50 \%$ lower clearance of unbound paclitaxel in patients aged $\geqslant 70$ years [39]. These results were supported by four larger studies showing an altered PK profile in elderly patients compared to their younger peers [40-43]. However, additional analyses of data from both large studies by Joerger et al. ( $n=168, n=273$, respectively) showed that this age effect was predominantly driven by the youngest age group, with no PK differences in patients over 70 years of age compared to their younger peers. It remains uncertain whether elderly patients treated with paclitaxel in clinical practice have a similar PK profile compared to their younger peers, although recent large studies imply a small impact of age on paclitaxel PK [40-42]. Given the high inter- and intra-patient variability in paclitaxel PK, it seems implausible that any potential age-related PK difference has relevance in routine clinical practice.

\subsection{Anthracyclines}

\subsubsection{Doxorubicin}

Doxorubicin has a high volume of distribution with extensive tissue uptake, moderate plasma protein binding and is metabolized by CYP enzymes [44,45]. About $50 \%$ of the parent drug is excreted in the bile, while $30 \%$ of doxorubicin is excreted as conjugates. Five to $12 \%$ of the drug is excreted renally. Due to physiological changes in the elderly, a different PK profile may be expected. FDA's SmpC reported no overall differences in safety and effectiveness in elderly patients (estimated $n=4600$ ) compared to younger patients. Conversely, the SmpC also recommended to consider a lower dose or longer interval between cycles in elderly women with metastatic breast cancer, without providing support or references [45]. Relatively small studies ( $n=14$ and $n=27$, respectively) found no influence of advanced age on the clearance of doxorubicin [46,47], although one of these studies noted a trend towards a lower volume of distribution in elderly patients [47]. On the contrary, Robert et al. reported a significant decrease in the distribution phase in two different study populations $(n=37$ with breast cancer, lymphoma or other tumors and $n=26$ with solid tumors, respectively) [48]. However, increasing age did not significantly influence total clearance in these study populations. A subsequent pooled analysis of four small clinical trials by Li et al. $(n=56)$ supported this significant age-dependent impact on the distribution phase of doxorubicin. This study showed that initial doxorubicin concentrations were higher in the elderly patient due to a slower distribution of the drug into peripheral compartments, most probably due to altered regional blood flow. Furthermore, Li et al. described a small, but significant inverse correlation between age and total doxorubicin clearance [49]. These findings were supported by a study including 65 breast cancer patients, showing a significant $9 \%$ decrease in doxorubicin clearance per 10-year increase in age [50]. Overall, it seems questionable that these possible PK differences have clinical relevance in routine clinical practice.

\subsubsection{Epirubicin}

Epirubicin is extensively and rapidly metabolized in the liver and eliminated in the bile [51]. In one study, including 78 breast cancer patients, no relevant age-related differences in PK of epirubicin were found. However, the number of elderly patients included in this study was not provided [52]. In another PK study $(n=36)$, on the contrary, a significant influence of increasing age on epirubicin clearance was observed, although it should be noted that only one patient aged over 70 was included in this analysis [53]. This finding was supported by a study including 66 breast cancer patients, showing 
an increased epirubicin maximum serum concentration with increasing age [54]. Based on these results, more rigorous monitoring in elderly women was recommended by the FDA [55,56].

\subsection{Alkylating Agents}

\subsubsection{Cyclophosphamide}

Cyclophosphamide is a prodrug with low protein binding $(24 \%)$, which is activated in the liver, predominantly by CYP2B6, CYP2C9 and CYP3A4, and shows autoinduction after repeated administration [57]. Following intravenous administration, cyclophosphamide is primarily excreted as metabolites, while $10 \%-20 \%$ is excreted unchanged in the urine and $4 \%$ is excreted in the bile. The impact of liver dysfunction on cyclophosphamide PK remains unclear at present, with some reports showing no association, while others reported increased toxicity and even hepatic failure [57-59]. Overall, insufficient data are available to provide specific advice for the elderly patient, although cautious dose selection is advised in this patient group [59]. One small and one moderate-sized study ( $n=14, n=65$, respectively) showed no apparent impact of patient age on the clearance of cyclophosphamide $[47,50]$.

\subsection{Vinca-Alkaloids}

\subsubsection{Vinorelbine (Intravenous)}

Vinorelbine shows plasma protein binding between $60 \%$ and $91 \%$ and is extensively metabolized by the liver via CYP3A, with a renal clearance of only $11 \%$ [60]. Several small to moderate-sized clinical trials showed no correlation between age and elimination of vinorelbine [61-65]. Gauvin and colleagues, however, described a significant age-related decrease of vinorelbine clearance in two clinical studies that exclusively included patients over the age of 66 years, thus lacking a control group of younger patients. As acknowledged by the authors, the age-associated difference in clearance was mainly driven by the age group of $66-70$ years $[66,67]$. Furthermore, differences in assay sensitivity, matrices used for PK analysis, divergent sampling times and duration and different patient populations may explain differences in PK parameters in these studies. Overall, available data do not support individual dosing based on patient age, as acknowledged by the drug's SmPC [68].

\subsubsection{Vinorelbine (Oral)}

Oral administration of vinorelbine may be an attractive alternative to intravenous vinorelbine for elderly patients, who are often affected by poor venous access. However, oral vinorelbine has been associated with severe and potentially fatal neutropenia, which was associated with high drug exposure [69]. Subsequently, an intraindividual dose escalation regimen was developed, which has received market access in several European and Asian countries and Australia, but has not received market approval in the USA [70-72]. The average bioavailability of the oral formulation of vinorelbine ranges from $33 \%-43 \%$, with linear elimination similar to the intravenous formulation $[63,64,73,74]$. Several phase I/II studies showed no significant difference in PK parameters between the elderly population and their younger counterparts. Although some studies used historical data as a control, all results from separate study analyses and pooled data analyses suggested that increasing age has no clinically-relevant impact on vinorelbine PK $[63,74,75]$.

\subsection{Anti-Metabolites}

\subsubsection{5-Fluorouracil}

After intravenous administration, 5-fluorouracil (5-FU) shows low protein binding and has a high apparent volume of distribution [76]. It is predominantly metabolized in the liver, where the enzyme dihydropyrimidine dehydrogenase (DPD) plays a crucial role in the deactivation of 5-FU $[77,78]$. 
After intravenous administration, approximately $90 \%$ of the dose of 5 -FU is undergoing metabolic inactivation via DPD, and a small percentage undergoes renal excretion. In one study, a significant influence of aging on the AUC of 5-FU was documented, although the authors noted that the effect was weak with a remaining unexplained variation in AUC of more than $60 \%$ [79]. Another small study showed a non-significant trend towards lower clearance in the elderly patient [80]. These results were countered by three moderate to large-sized studies $(n=380, n=103$ and $n=31$, resp.) showing no PK differences in the elderly population [81-83]. These data supported the SmPC's statement that specific dosing recommendations solely based on a patient's age are not necessary [84].

\subsubsection{Capecitabine}

After oral administration, capecitabine is sequentially converted to $5^{\prime}$-deoxy-5-fluorocytidine (DFCR) by hepatic carboxylesterase and to $5^{\prime}$-deoxy-5-fluorouridine (DFUR) by CDA. The intermediate DFUR is converted to 5 -FU by the enzyme thymidine phosphorylase in the final activating step. This protein has higher activity in tumor than in normal tissue. Although oral administration may be preferable in the elderly population, there is conflicting data as to whether elderly patients have a higher risk of developing severe toxicity with capecitabine compared to intravenous 5-FU $[85,86]$. Renal function and comorbidity were identified as independent predictors of dose reductions in elderly patients with colon cancer [87]. Twelves et al. showed that patients aged $\geqslant 70$ years received significantly more dose reductions than their younger peers (51\% vs. 39\%) during capecitabine treatment [88]. Although not formally advised, several studies proposed a lower starting dose of $1000 \mathrm{mg} / \mathrm{m}^{2}$ twice daily instead of $1250 \mathrm{mg} / \mathrm{m}^{2}$ BID for elderly patients $[87,89,90]$. However, the optimal dose for elderly patients remains controversial, with conflicting study results and inadequate efficacy data to support lower starting doses [91-94]. Additionally, these trials were designed to evaluate toxicity profiles in elderly patients, and no PK data were available [85-90,94]. In FDA's medical review at approval, a meta-analysis of phase I studies ( $n=85$, range 33-77 years) was performed, showing an increase in AUC and Cmax of $\alpha$-fluoro- $\beta$-alanine (FBAL), the major renally-excreted metabolite, in elderly patients compared to their younger peers. This difference in FBAL PK was ascribed to altered renal function rather than aging [95]. In a pooled data analysis conducted by the FDA in 505 patients, a $15 \%$ increase in AUC of FBAL was described per $20 \%$ increase in age. However, no influence of age on the PK of 5-FU or other metabolites has been shown [96]. Although the impact of FBAL plasma concentrations on clinical toxicity remains unclear, clinically-relevant effects are not expected [97-101]. In one moderate-sized PK study, a lower capecitabine clearance in elderly patients was found $(n=29)$, which the authors attributed to the overall number of women included. As no differences in PK of the metabolites 5'-deoxy-5-fluorocytidine, 5'-deoxy-5-fluorouridine (DFUR) and the active 5-FU were reported, no dose adjustments were recommended for elderly patients [102]. Another moderate-sized study $(n=25)$ showed no influence of age, gender, BSA or creatinine clearance on PK parameters [98]. This was supported by a population PK analysis study including 20 elderly patients, compared to PK data of 40 younger patients from two previous clinical trials, showing no effect of age on the clearance of capecitabine and its metabolites. Although a difference in absorption by age was documented, the authors reported this as not having clinical relevance [101]. According to the drug's SmPC, capecitabine should be used cautiously in elderly patients. EMA stated that no adjustment of the starting dose is needed, whereas according to the FDA, there is insufficient data to recommend specific dose adaptations for older patients $[96,103]$. Analysis at approval was in line with subsequent studies showing no clinically-relevant effect of aging on capecitabine PK. Still, elderly patients develop more pronounced toxicity from capecitabine on average, potentially due to reduced organ function, and a reduced initial dosing of the drug may be justified accordingly. 


\subsection{Platinum Agents}

\subsubsection{Carboplatin}

Carboplatin binds irreversibly to plasma proteins. The drug mainly undergoes renal excretion [104]. In clinical practice, carboplatin is dosed based on estimates of GFR, typically by using the Calvert formula. This results in a more predictable individual drug exposure as assessed by the area under the plasma concentration curve (AUC) and minimizes the risk of toxicity, especially in elderly patients with renal dysfunction. However, there remains some controversy about which formula may best predict target AUC in elderly patients [105,106]. In a phase I study including 55 patients receiving carboplatin dosed in $\mathrm{mg} / \mathrm{m}^{2}$, a significant increase in mean plasma ultrafiltrate AUC of carboplatin was observed with increasing age [43]. In a more recent study $(n=24)$, elderly patients received carboplatin AUC 4 (mg/min/Ml) versus carboplatin AUC 5 in their younger counterparts, as calculated with the Calvert-Cockcroft-Gault formula. Despite this per protocol dose adjustment, exposure was similar in both groups. Age was a significant predictor of carboplatin clearance, showing a $31 \%$ mean clearance decrease in patients aged 70 years or over compared to younger patients [107].

\subsubsection{Cisplatin}

Cisplatin binds rapidly and irreversible to proteins. Free platinum is mainly eliminated renally [108,109]. Cisplatin is formally contraindicated in patients with a measured or calculated GFR $<60 \mathrm{~mL} / \mathrm{min}$ [110-112], although dose adjustments may be applied with decreased renal function in clinical practice. In a moderate-sized PK study $(n=22)$, lower creatinine clearance was significantly associated with cisplatin maximum plasma concentrations (Cmax) [113]. Although the influence of age on cisplatin PK was not tested in this analysis, results could justify dose reductions or prolonged infusion of cisplatin in elderly patients with an associated decreases in renal function. In a single PK study $(n=23)$ including patients with normal renal function, increasing age was a significant predictor of lower clearance of total and free fraction platinum [114]. It should be mentioned, however, that cisplatin-associated nephrotoxicity was not increased in elderly patients, whereas increased myelosuppression was seen in some elderly patients receiving cisplatin, making arbitrary dose reductions based solely on aging disputable [111,115-117].

\subsection{Monoclonal Antibodies}

\subsubsection{Trastuzumab}

Trastuzumab is a monoclonal antibody directed against the extracellular HER-2 receptor that is overexpressed in roughly $25 \%$ of breast cancer patients. After intravenous administration, trastuzumab undergoes target-directed distribution and elimination by the reticuloendothelial system and tissue turnover, with a long terminal half-life of 3-4 weeks. Trastuzumab is approved in patients with HER2-positive breast cancer in the early or advanced stage. While trastuzumab is given as a three-weekly intravenous infusion in early-stage breast cancer [118], it is usually given as a weekly infusion in patients with metastatic breast cancer [119]. In a large pooled dataset of 164 patients with early-stage and 76 patients with metastatic breast cancer, the authors performed a population PK-PD analysis to assess trastuzumab-associated cardiotoxicity [120]. While patient age was found to be a significant covariate on the relationship between trastuzumab PK and the trastuzumab-associated decrease of left ventricular ejection fraction (LVEF), the impact of patient age was considered marginal. Given the fact that trastuzumab-associated cardiotoxicity is the clinically most important adverse event, the analysis by van Hasselt and colleagues strongly argues against age-dependent dosing of trastuzumab. Monitoring of cardiac function at baseline and during trastuzumab treatment, however, is of substantial importance to keep a favorable benefit-risk profile also in the elderly breast cancer patient. This is also in agreement with data as described for the trastuzumab antibody-drug conjugate T-DM1 (see below). 


\subsubsection{Trastuzumab Emtansine (Antibody-Drug Conjugate)}

Trastuzumab emtansine (T-DM1) is a novel antibody-drug conjugate, which is composed of trastuzumab coupled through a stable thioether linker to mertansine, an anti-microtubule cytotoxic agent [121]. T-DM1 received fast-track market approval in 2013 in the European Union and the United States based on one large pivotal trial [122,123]. T-DM1 undergoes proteolytic degradation similar to trastuzumab. Yet, drug clearance of T-DM1 was faster than trastuzumab clearance, which may be ascribed to the addition of the deconjugation clearance pathway of T-DM1 [124]. Population PK analysis of multiple phase I-III studies revealed no influence of aging on the PK of trastuzumab emtansine in large datasets $[125,126]$. This is in line with the official label stating that age has no clinically meaningful effect on trastuzumab emtansine PK [121].

\subsection{Tubulin Inhibitors}

\subsubsection{Eribulin Mesylate}

Eribulin mesylate is a microtubule inhibitor with cytotoxic properties. No major metabolites were found in human plasma, and it is predominantly excreted unchanged in the feces. Renal excretion of eribulin mesylate was shown to be less than 10\% [127]. Eribulin received FDA and EMA approval for the treatment of locally-advanced or metastatic breast cancer refractory to both anthracyclines and taxanes. According to the drug's SmPC, no specific dose adjustment is recommended in elderly patients, based on a similar safety profile, except for an increased proportion of asthenia/fatigue in elderly patients $[128,129]$. In the available FDA review for approval, a separate PK analysis of elderly ( $\geqslant 65$ years, $n=63$ ) versus younger patients ( $<65$ years, $n=206$ ) was provided. This analysis showed that the median clearance of eribulin mesylate was not influenced by age [130].

\subsection{Oral Targeted Anti-Cancer Agents}

\subsubsection{Everolimus}

Everolimus is an oral inhibitor of the mTOR pathway that is extensively metabolized in the liver and predominantly eliminated through the bile. It is a substrate for CYP3A4, as well as for PgP [131]. The FDA's SmPC stated that the clearance of everolimus is not dependent on age [132]. Although this was not described in the pivotal trial itself [133], a thorough description was provided in the FDA's drug approval review $(n=61)$ [134]. Furthermore, a study performed by $\mathrm{Xu}$ and colleagues supported the lack of association between patient age and the PK of everolimus. Since this is not reported in the results section, but merely noted in the discussion, it is likely that this comment refers to FDA's drug SmPC [135].

\subsubsection{Lapatinib}

Lapatinib is a HER2 and EGFR targeted kinase inhibitor. It shows a variable bioavailability due to its low solubility and first-pass metabolism by CYP3A4/5. After gastrointestinal absorption, lapatinib is highly protein bound ( $99 \%$ ) to albumin and alpha-1-acid-glycoprotein. Elimination is predominantly mediated by CYP3A4/5, whereas renal elimination accounted for less than $2 \%$ [136]. As stated by the FDA and EMA, there are no dosing recommendations provided for elderly patients as no data are available on the age-related PK of lapatinib [137-140]. Although no influence of higher age on the PK was described for several other -nibs [141], "absence of evidence is not evidence of absence" of any association between patient age and lapatinib PK, as no studies were available investigating the influence of aging on lapatinib PK [138].

\section{Discussion}

This article summarizes existing evidence on the impact of patient age on the PK of anticancer drugs used for the treatment of breast cancer (excluding endocrine drugs). Although PK results 
published on many anticancer drugs are conflicting, there is reasonable evidence for patient age to impact the PK of taxanes, anthracyclines, vinorelbine, capecitabine and platinum compounds. On the other side, potential PK differences in the aging population did not appear to be clinically relevant in the case of docetaxel, doxorubicin, vinorelbine and capecitabine. Additional analysis of paclitaxel also implies no clinically-relevant PK differences in the elderly. Furthermore, there is no indication that age influences the PK of cyclophosphamide, although data are limited. Even though no age-related PK differences were observed with several oral tyrosine kinase inhibitors [141], no PK analyses were conducted in elderly patients using lapatinib; hence, a potential difference cannot be ruled out.

Recent market approval of several newer anticancer drugs was accompanied by comprehensive population PK analyses to evaluate the influence of various covariates on the drug's PK, including patient age. For eribulin mesylate, trastuzumab emtansine and everolimus, these model-based analyses showed no age-associated differences in drug PK, suggesting that the approved dosing regimen can be applied in elderly patients. It should be borne in mind, however, that these results were based on elderly patients who fulfilled the eligibility criteria of the respective clinical trial, thus including a homogeneous patient group with a good performance status. Due to the inclusion and exclusion criteria, these results cannot plainly be extrapolated to the elderly patient population in daily practice. Another important issue is the threshold beyond which changes in PK parameters are suggested to be clinically relevant. While no guidelines on handling and interpreting PK parameters with regards to clinical relevance have been published to our knowledge, some data have been published on the interpretation of covariate models in oncology, and a quantitative impact of at least $20 \%$ has been suggested for respective covariates on major PK parameters, mainly drug elimination, to suggest clinical relevance [142]. Finally, there is still the need to individually interpret the respective data for potential clinical relevance, and the use of data simulations may be one strategy for supporting data interpretation.

By design, different cut-off values were used in the literature to define the "elderly population", using a threshold of 65,70 or 75 years, respectively. Furthermore, many published studies were not powered to analyze age-related effects on anticancer drug PK. In the available elderly trials, the need for adequate PK-PD research in the heterogeneous elderly population was acknowledged, which is reflected by a lack of specific recommendations per anticancer drug for elderly women in the current breast cancer guidelines [143-147]. Some published guidelines have completely abstained from mentioning the elderly population [144-146]. The guidelines of the American Association of Clinical Oncology (ASCO) on advanced HER2-positive breast cancer however support the need for high quality data in elderly patients, yet omit providing specific treatment advice for the elderly population [143]. The respective European breast cancer guidelines state that treatment decisions should not be age dependent. The authors acknowledge that, although controversial, dose reductions and treatment regimen modifications are increasingly applied with increasing age. While combination chemotherapy is clearly more effective in the adjuvant breast cancer setting, single-agent sequential chemotherapy is advised to be the preferred option for elderly women with metastatic disease [147]. Growing emphasis on the influence of increasing age on treatment choice and outcome is discernible in several recent guidelines $[143,147,148]$. However, a paucity of adequate evidence-based data and conflicting trial results deters conclusive treatment strategies for the heterogeneous group of elderly patients treated in routine clinical practice. If substantial dose adaptations or dose reductions are considered in an elderly breast cancer patient, clinicians should consider the following issues: (1) potential organ dysfunction as a clear argument for impaired drug clearance; (2) extensive pretreatment with ensuing impairment of bone marrow reserve; (3) looking at objective geriatric scales, such as the Comprehensive Geriatric Assessment (CGA) or the Geriatric Prognostic Index (GPI) [149-152] to quantitate potential impairment of the general performance status; (4) checking for potential drug-drug interactions and polypharmacy; (5) a clinical pharmacologist to discuss with patients, if possible.

The PK profile of an anticancer drug in the elderly is not the sole predictor of treatment tolerability, as pharmacodynamic differences may also play an important role [153]. With docetaxel, for instance, 
an increased incidence of hematologic toxicity in the elderly [25,27] may be ascribed to deprivation of bone marrow and/or a greater sensitivity of bone marrow function to this chemotherapeutic agent without PK alterations. Altogether, this complicates a well-balanced management of the optimal choice of treatment and its corresponding dosage in the large group of elderly patients in daily practice. Ideally, clinical dosing regimens should be tailored to the specific patient (group). In order to predict the best standard of care for the heterogeneous group of elderly patients, it is important to clarify which factors influence the PK profile of anticancer drugs and to what extent. Therefore, it is of importance to include a representative subpopulation of geriatric patients in clinical trials and observational studies. Promising approaches to improve adequate PK-PD data acquisition in geriatric patients include: (1) pharmacometric modelling and clinical trial simulation techniques; (2) specific comorbidity and drug interaction studies; (3) optimal guidance and timely interaction with regulatory agencies; and (4) a holistic approach for the older cancer patient including international geriatric assessments, such as the Comprehensive Geriatric Assessment (CGA) or the Geriatric Prognostic Index (GPI) [150-153], and tailored study endpoints, including, e.g., impact on quality of life. Although some of these approaches are already being implemented in drug development programs and clinical practice, they should routinely be employed to achieve well-defined risk-benefit evaluations of treatment regimens used in the elderly population.

\section{Conclusions}

Selected published data revealed differences in the effect and magnitude of increasing age on PK of several anticancer drugs. There may be a clinically-relevant age-related PK difference for anthracyclines and platina agents. In the majority of cases, age is not a good surrogate marker for anticancer drug pharmacokinetics, and the physiological state of the individual patient may better be approached by looking at organ function, Charlson Comorbidity Score or geriatric functional assessment.

\section{References}

1. Smith, B.D.; Smith, G.L.; Hurria, A.; Hortobagyi, G.N.; Buchholz, T.A. Future of cancer incidence in the United States: Burdens upon an aging, changing nation. J. Clin. Oncol. 2009, 27, 2758-2765. [CrossRef] [PubMed]

2. International Conference on Harmonisation. Studies in Support of Special Populations: Geriatrics—E7; European Medicines Agency: London, UK, 1993.

3. Rothwell, P.M. External validity of randomised controlled trials: "To whom do the results of this trial apply?". Lancet 2005, 365, 82-93. [CrossRef]

4. Zulman, D.M.; Sussman, J.B.; Chen, X.; Cigolle, C.T.; Blaum, C.S.; Hayward, R.A. Examining the evidence: A systematic review of the inclusion and analysis of older adults in randomized controlled trials. J. Gen. Intern. Med. 2011, 26, 783-790. [CrossRef] [PubMed]

5. Murthy, V.H.; Krumholz, H.M.; Gross, C.P. Participation in cancer clinical trials: Race-, sex, and aged-based disparities. Prim. Care 2004, 291, 2720-2726. [CrossRef] [PubMed]

6. Lewis, J.H.; Kilgore, M.L.; Goldman, D.P.; Trimble, E.L.; Kaplan, R.; Montello, M.J.; Housman, M.G.; Escarce, J.J. Participation of patients 65 years of age or older in cancer clinical trials. J. Clin. Oncol. 2003, 21, 1383-1389. [CrossRef] [PubMed]

7. Villella, J.; Chalas, E. Optimising treatment of elderly patients with ovarian cancer: Improving their enrollment in clinical trials. Drugs Aging 2005, 22, 95-100. [CrossRef] [PubMed]

8. International Conference on Harmonisation. Dose-Response Information to Support Drug Registration-E4; European Medicines Agency: London, UK, 1994.

9. Food and Drug Administration. Guidance for Industry: Exposure-Response Relationships—Study Design, Data Analysis and Regulatory Applications; FDA: Rockville, MD, USA, 2003. 
10. Bastiaannet, E.; Liefers, G.J.; de Craen, A.J.M.; Kuppen, P.J.K.; van de Water, W.; Portielje, J.E.A.; van der Geest, L.G.M.; Janssen-Heijnen, M.L.G.; Dekkers, O.M.; van de Velde, C.J.H.; et al. Breast cancer in elderly compared to younger patients in the Netherlands: Stage at diagnosis, treatment and survival in 127,805 unselected patients. Breast Cancer Res. Treat. 2010, 124, 801-807. [CrossRef] [PubMed]

11. Klotz, U. Pharmacokinetics and drug metabolism in the elderly. Drug Metab. Rev. 2009, 41, 67-76. [CrossRef] [PubMed]

12. Wynne, H.A. Drug metabolism and ageing. J. Br. Menopause Soc. 2005, 11, 51-56. [CrossRef] [PubMed]

13. Cusack, B.J. Pharmacokinetics in older persons. Am. J. Geriatr. Pharmacother. 2004, 2, 274-302. [CrossRef] [PubMed]

14. Turnheim, K. Drug therapy in the elderly. Exp. Gerontol. 2004, 39, 1731-1738. [CrossRef] [PubMed]

15. Kiderlen, M.; de Glas, N.A.; Bastiaannet, E.; van de Water, W.; de Craen, A.J.M.; Guicherit, O.R.; Merkus, J.W.S.; Extermann, M.; van de Velde, C.J.H.; Liefers, G.J. Impact of comorbidity on outcome of older breast cancer patients: A FOCUS cohort study. Breast Cancer Res. Treat. 2014, 145, 185-192. [CrossRef] [PubMed]

16. Popa, M.A.; Wallace, K.J.; Brunello, A.; Extermann, M.; Balducci, L. Potential drug interactions and chemotoxicity in older patients with cancer receiving chemotherapy. J. Geriatr. Oncol. 2015, 5, 307-314. [CrossRef] [PubMed]

17. Srokowski, T.P.; Fang, S.; Hortobagyi, G.N.; Giordano, S.H. Impact of diabetes mellitus on complications and outcomes of adjuvant chemotherapy in older patients with breast cancer. J. Clin. Oncol. 2009, 27, 2170-2176. [CrossRef] [PubMed]

18. Satariano, W.A.; Ragland, D.R. The effect of comorbidity on 3-year survival of women with primary breast cancer. Ann. Intern. Med. 1994, 120, 104-110. [CrossRef] [PubMed]

19. Yancik, R.; Wesley, M.N.; Ries, L.A.; Havlik, R.J.; Edwards, B.K.; Yates, J.W. Effect of age and comorbidity in postmenopausal breast cancer patients aged 55 years and older. JAMA 2001, 285, 885-892. [CrossRef] [PubMed]

20. Food and Drug Administration. Taxotere (docetaxel), NDA 020449Adriamycin RDF (Doxorubin Hydrochloride), NDA 050467. 2011.

21. DRUGDEX ${ }^{\circledR}$. Docetaxel; Truven Health Analytics: Thomson Micromedex, Greenwood Village, CO, USA, 2015.

22. Clarke, S.J.; Rivory, L.P. Clinical pharmacokinetics of docetaxel. Clin. Pharmacokinet. 1999, 36, 99-114. [CrossRef] [PubMed]

23. John, V.; Mashru, S.; Lichtman, S. Pharmacological factors influencing anticancer drug selection in the elderly. Drugs Aging 2003, 20, 737-759. [CrossRef] [PubMed]

24. Schmucker, D.L. Liver function and phase I drug metabolism in the elderly: A paradox. Drugs Aging 2001, 18, 837-851. [CrossRef] [PubMed]

25. Minami, H.; Ohe, Y.; Niho, S.; Goto, K.; Ohmatsu, H.; Kubota, K.; Kakinuma, R.; Nishiwaki, Y.; Nokihara, H.; Sekine, I.; et al. Comparison of pharmacokinetics and pharmacodynamics of docetaxel and cisplatin in elderly and non-elderly patients: Why is toxicity increased in elderly patients? J. Clin. Oncol. 2004, 22, 2901-2908. [CrossRef] [PubMed]

26. Slaviero, K.A.; Clarke, S.J.; McLachlan, A.J.; Blair, E.Y.L.; Rivory, L.P. Population pharmacokinetics of weekly docetaxel in patients with advanced cancer. Br. J. Clin. Pharmacol. 2004, 57, 44-53. [CrossRef] [PubMed]

27. Ten Tije, A.J.; Verweij, J.; Carducci, M.A.; Graveland, W.; Rogers, T.; Pronk, T.; Verbruggen, M.P.; Dawkins, F.; Baker, S.D. Prospective evaluation of the pharmacokinetics and toxicity profile of docetaxel in the elderly. J. Clin. Oncol. 2005, 23, 1070-1077. [CrossRef] [PubMed]

28. Hurria, A.; Fleming, M.T.; Baker, S.D.; Kelly, W.K.; Cutchall, K.; Panageas, K.; Caravelli, J.; Yeung, H.; Kris, M.G.; Gomez, J.; et al. Pharmacokinetics and toxicity of weekly docetaxel in older patients. Clin. Cancer Res. 2006, 12, 6100-6105. [CrossRef] [PubMed]

29. Yamamoto, N.; Tamura, T.; Kamiya, Y.; Sekine, I.; Kunitoh, H.; Saijo, N. Correlation between docetaxel clearance and estimated cytochrome $\mathrm{P} 450$ activity by urinary metabolite of exogenous cortisol. J. Clin. Oncol. 2000, 18, 2301-2308. [PubMed] 
30. Michael, M.; Cullinane, C.; Hatzimihalis, A.; O'Kane, C.; Milner, A.; Booth, R.; Schlicht, S.; Clarke, S.J.; Francis, P. Docetaxel pharmacokinetics and its correlation with two in vivo probes for cytochrome P450 enzymes: The C 14-erythromycin breath test and the antipyine clearance test. Cancer Chemother. Pharmacol. 2012, 69, 125-135. [CrossRef] [PubMed]

31. Bruno, R.; Vivier, N.; Veyat-Follet, C.; Montay, G.; Rhodes, G.R. Population pharmacokinetics and pharmacokinetic-pharmacodynamic relationships for docetaxel. Investig. New Drugs 2001, 19, 163-169. [CrossRef]

32. European Medicines Agency. Committee for Medicinal Products for Human Use. In Scientific Discussion: Taxotere (Docetaxel); European Medicines Agency: London, UK, 2005.

33. European Medicines Agency. Taxotere (Docetaxel); European Medicines Agency: London, UK, 2015.

34. DRUGDEX ${ }^{\circledR}$. Paclitaxel; Truven Health Analytics: Thomson Micromedex, Greenwood Village, CO, USA, 2015.

35. Henningsson, A.; Karlsson, M.O.; Viganò, L.; Gianni, L.; Verweij, J.; Sparreboom, A. Mechanism-based pharmacokinetic model for paclitaxel. J. Clin. Oncol. 2001, 19, 4065-4073. [PubMed]

36. Nakamura, Y.; Sekine, I.; Furuse, K.; Saijo, N. Retrospective comparison of toxicity and efficacy in phase II trials of 3-h infusions of paclitaxel for patients 70 years of age or older and patients under 70 years of age. Cancer Chemother. Pharmacol. 2000, 46, 114-118. [CrossRef] [PubMed]

37. Fidias, P.; Supko, J.G.; Martins, R.; Boral, A.; Carey, R.; Grossbard, M.; Shapiro, G.; Ostler, P.; Lucca, J.; Johnson, B.E.; et al. Measurement and impact of co-morbidity in elderly patients with advanced non-small cell lung cancer treated with chemotherapy. A phase II study of weekly paclitaxel. Clin. Cancer Res. 2001, 7, 3942-3949. [PubMed]

38. Borkowski, J.M.; Duerr, M.; Donehower, R.C.; Rowinsky, E.K.; Chen, T.L.; Ettinger, D.S.; Grochow, L.B. Relation between age and clearance rate of nine investigational anticancer drugs from phase I pharmacokinetic data. Cancer Chemother. Pharmacol. 1994, 33, 493-496. [CrossRef] [PubMed]

39. Smorenburg, C.H.; ten Tije, A.J.; Verweij, J.; Bontenbal, M.; Mross, K.; Van Zomeren, D.M.; Seynaeve, C.; Sparreboom, A. Altered clearance of unbound paclitaxel in elderly patients with metastatic breast cancer. Eur. J. Cancer 2003, 39, 196-202. [CrossRef]

40. Joerger, M.; Huitema, A.D.R.; van den Bongard, D.H.J.G.; Schellens, J.H.M.; Beijnen, J.H. Quantitative effect of gender, age, liver function, and body size on the population pharmacokinetics of Paclitaxel in patients with solid tumors. Clin. Cancer Res. 2006, 12, 2150-2157. [CrossRef] [PubMed]

41. Joerger, M.; Kraff, S.; Huitema, A.D.R.; Feiss, G.; Moritz, B.; Schellens, J.H.M.; Beijnen, J.H.; Jaehde, U. Evaluation of a pharmacology-driven dosing algorithm of 3-weekly paclitaxel using therapeutic drug monitoring: A pharmacokinetic-pharmacodynamic simulation study. Clin. Pharmacokinet. 2012, 51, 607-617. [CrossRef] [PubMed]

42. Lichtman, S.M.; Hollis, D.; Miller, A.A.; Rosner, G.L.; Rhoades, C.A.; Lester, E.P.; Millard, F.; Byd, J.; Cullinan, S.A.; Rosen, D.M.; et al. Prospective evaluation of the relationship of patient age and paclitaxel clinical pharmacology: Cancer and Leukemia Group B (CALGB 9762). J. Clin. Oncol. 2006, 24, 1846-1851. [CrossRef] [PubMed]

43. Huizing, M.T.; Giaccone, G.; van Warmerdam, L.J.; Rosing, H.; Bakker, P.J.; Vermorken, J.B.; Postmus, P.E.; van Zandwijk, N.; Koolen, M.G.; ten Bokkel Huinink, W.W.; et al. Pharmacokinetics of paclitaxel and carboplatin in a dose-escalating and dose-sequencing study in patients with non-small-cell lung cancer. The European Cancer Centre. J. Clin. Oncol. 1997, 15, 317-329. [PubMed]

44. DRUGDEX ${ }^{\circledR}$. Doxorubicin Hydrochloride; Truven Health Analytics: Thomson Micromedex, Greenwood Village, CO, USA, 2015.

45. Food and Drug Administration. Adriamycin RDF (Doxorubin Hydrochloride), NDA 050467, 2013.

46. Dobbs, N.A.; Twelves, C.J.; Gillies, H.; James, C.A.; Harper, P.G.; Rubens, R.D. Gender affects doxorubicin pharmacokinetics in patients with normal liver biochemistry. Cancer Chemother. Pharmacol. 1995, 36, 473-476. [CrossRef] [PubMed]

47. Dees, E.C.; O’Reilly, S.; Goodman, S.N.; Sartorius, S.; Levine, M.A.; Jones, R.J.; Grochow, L.B.; Donehower, R.C.; Fetting, J.H. A prospective pharmacologic evaluation of age-related toxicity of adjuvant chemotherapy in women with breast cancer. Cancer Investig. 2000, 18, 521-529. [CrossRef]

48. Robert, J.; Hoerni, B. Age dependence of the early-phase pharmacokinetics of doxorubicin. Cancer Res. 1983, 43, 4467-9. [PubMed] 
49. Li, J.; Gwilt, P.R. The effect of age on the early disposition of doxorubicin. Cancer Chemother. Pharmacol. 2003, 51,395-402. [PubMed]

50. Joerger, M.; Huitema, A.D.R.; Richel, D.J.; Dittrich, C.; Pavlidis, N.; Briasoulis, E.; Vermorken, J.B.; Strocchi, E.; Martoni, A.; Sorio, R.; et al. Population pharmacokinetics and pharmacodynamics of doxorubicin and cyclophosphamide in breast cancer patients: A study by the EORTC-PAMM-NDDG. Clin. Pharmacokinet. 2007, 46, 1051-1068. [CrossRef] [PubMed]

51. DRUGDEX ${ }^{\circledR}$. Epirubicin Hydrochloride; Truven Health Analytics: Thomson Micromedex, Greenwood Village, CO, USA, 2015.

52. Jakobsen, P.; Steiness, E.; Bastholt, L.; Dalmark, M.; Lorenzen, A.; Petersen, D.; Gjedde, S.B.; Sandberg, E.; Rose, C.; Nielsen, O.S.; et al. Multiple-dose pharmacokinetics of epirubicin at four different dose levels: Studies in patients with metastatic breast cancer. Cancer Chemother. Pharmacol. 1991, 28, 63-68. [CrossRef] [PubMed]

53. Wade, J.R.; Kelman, A.W.; Kerr, D.J.; Robert, J.; Whiting, B. Variability in the pharmacokinetics of epirubicin: A population analysis. Cancer Chemother. Pharmacol. 1992, 29, 391-395. [CrossRef] [PubMed]

54. Eksborg, S.; Hardell, L.; Bengtsson, N.O.; Sjödin, M.; Elfsson, B. Epirubicin as a single agent therapy for the treatment of breast cancer-A pharmacokinetic and clinical study. Med. Oncol. Tumor Pharmacother. 1992, 9, 75-80. [PubMed]

55. Food and Drug Administration. Ellence (Epirubicin Hydrochloride), NDA 050778, 2014.

56. Food and Drug Administration, Center for Drug Evaluation and Research. Clinical Pharmacology and Biopharmaceutics Review: Ellence (Epirubicin Hydrochloride); FDA: Rockville, MD, USA, 1999.

57. DRUGDEX ${ }^{\circledR}$. Cyclophosphamide; Truven Health Analytics: Thomson Micromedex, Greenwood Village, CO, USA, 2015.

58. Moore, M.J. Clinical pharmacokinetics of cyclophosphamide. Clin. Pharmacokinet. 1991, 20, $194-208$. [CrossRef] [PubMed]

59. Food and Drug Administration. Lyophilized Cytoxan (Cyclophosphamide), NDA 012142, 2013.

60. DRUGDEX ${ }^{\circledR}$. Vinorelbine Tartrate; Truven Health Analytics: Thomson Micromedex, Greenwood Village, CO, USA, 2015.

61. Sorio, R.; Robieux, I.; Galligioni, E.; Freschi, A.; Colussi, A.M.; Crivellari, D.; Saracchini, S.; Monfardini, S. Pharmacokinetics and tolerance of vinorelbine in elderly patients with metastatic breast cancer. Eur. J. Cancer 1997, 33, 301-303. [CrossRef]

62. Nguyen, L.; Tranchand, B.; Puozzo, C.; Variol, P. Population pharmacokinetics model and limited sampling strategy for intravenous vinorelbine derived from phase I clinical trials. Br. J. Clin. Pharmacol. 2002, 53, 459-468. [CrossRef] [PubMed]

63. Variol, P.; Nguyen, L.; Tranchand, B.; Puozzo, C. A simultaneous oral/intravenous population pharmacokinetic model for vinorelbine. Eur. J. Clin. Pharmacol. 2002, 58, 467-476. [CrossRef] [PubMed]

64. Lush, R.M.; McCune, J.S.; Tetteh, L.; Thompson, J.A.; Mahany, J.J.; Garland, L.; Suttle, A.B.; Sullivan, D.M. The absolute bioavailability of oral vinorelbine in patients with solid tumors. Cancer Chemother. Pharmacol. 2005, 56, 578-584. [CrossRef] [PubMed]

65. Wong, M.; Balleine, R.L.; Blair, E.Y.L.; McLachlan, A.J.; Ackland, S.P.; Garg, M.B.; Evans, S.; Farlow, D.; Collins, M.; Rivory, L.P.; et al. Predictors of vinorelbine pharmacokinetics and pharmacodynamics in patients with cancer. J. Clin. Oncol. 2006, 24, 2448-2455. [CrossRef] [PubMed]

66. Gauvin, A.; Pinguet, F.; Culine, S.; Astre, C.; Gomeni, R.; Bressolle, F. Bayesian estimate of vinorelbine pharmacokinetic parameters in elderly patients with advanced metastatic cancer. Clin. Cancer Res. 2000, 6, 2690-2695. [PubMed]

67. Gauvin, A.; Pinguet, F.; Culine, S.; Astre, C.; Gomeni, R.; Bressolle, F. A limited-sampling strategy to estimate individual pharmacokinetic parameters of vinorelbine in elderly patients with advanced metastatic cancer. Anticancer Drugs 2002, 13, 473-480. [CrossRef] [PubMed]

68. Food and Drug Administration. Navelbine (Vinorelbine), NDA 020388, 2014.

69. Depierre, A.; Freyer, G.; Jassem, J.; Orfeuvre, H.; Ramlau, R.; Lemarie, E.; Koralewski, P.; Mauriac, L.; Breton, J.L.; Delozier, T.; et al. Oral vinorelbine: Feasibility and safety profile. Ann. Oncol. 2001, 12, 1677-1681. [CrossRef] [PubMed] 
70. Colomer, R.; Alba, E.; González-Martin, A.; Paz-Ares, L.; Martín, M.; Llombart, A.; Rodríguez Lescure, A.; Salvador, J.; Albanell, J.; Isla, D.; et al. Treatment of cancer with oral drugs: A position statement by the Spanish Society of Medical Oncology (SEOM). Ann. Oncol. 2010, 21, 195-198. [CrossRef] [PubMed]

71. Pierre Fabre Press Release: Pierre Fabre Médicament Obtains MA in China for NAVELBINE ${ }^{\circledR}$ Oral (Vinorelbine) in the Treatment of Advanced Lung and Breast Cancer. Available online: http://www.pierre-fabre.com/sites/default/files/files/document/file/amm_chine_navelbine_oralven.pdf (accessed on 1 December 2015).

72. Therapeutic Goods Administration. Australian Public Assessment Report: Navelbine Oral (Vinorelbine Capsules); Therapeutic Goods Administration: Woden, Austrilia, 2012.

73. Marty, M.; Fumoleau, P.; Adenis, A.; Rousseau, Y.; Merrouche, Y.; Robinet, G.; Senac, I.; Puozzo, C. Oral vinorelbine pharmacokinetics and absolute bioavailability study in patients with solid tumors. Ann. Oncol. 2001, 12, 1643-1649. [CrossRef] [PubMed]

74. Puozzo, C.; Gridelli, C. Non-Small-Cell Lung Cancer in Elderly Patients: Influence of Age on Vinorelbine Oral Pharmacokinetics. Clin. Lung Cancer 2004, 5, 237-242. [CrossRef] [PubMed]

75. Gridelli, C.; Manegold, C.; Mali, P.; Reck, M.; Portalone, L.; Castelnau, O.; Stahel, R.; Betticher, D.; Pless, M.; Pons, J.T.; et al. Oral vinorelbine given as monotherapy to advanced, elderly NSCLC patients: A multicentre phase II trial. Eur. J. Cancer 2004, 40, 2424-2431. [CrossRef] [PubMed]

76. DRUGDEX ${ }^{\circledR}$. Fluorouracil; Truven Health Analytics: Thomson Micromedex, Greenwood Village, CO, USA, 2015.

77. Deenen, M.J.; Tol, J.; Burylo, A.M.; Doodeman, V.D.; de Boer, A.; Vincent, A.; Guchelaar, H.J.; Smits, P.H.M.; Beijnen, J.H.; Punt, C.J.A.; et al. Relationship between single nucleotide polymorphisms and haplotypes in DPYD and toxicity and efficacy of capecitabine in advanced colorectal cancer. Clin. Cancer Res. 2011, 17, 3455-3468. [CrossRef] [PubMed]

78. Cai, X.; Fang, J.M.; Xue, P.; Song, W.F.; Hu, J.; Gu, H.L.; Yang, H.Y.; Wang, L.W. The role of IVS14+1 G $>$ A genotype detection in the dihydropyimidine dehydrogenase gene and pharmacokinetic monitoring of 5-fluorouracil in the individualized adjustment of 5-fluorouracil for patients with local advanced and metastatic colorectal cancer: Eur. Rev. Med. Pharmacol. Sci. 2014, 18, 1247-1258.

79. Denham, J.W.; Ackland, S.P.; Burmeister, B.; Walpole, E.; Lamb, D.S.; Dady, P.; Spry, N.A. Causes for increased myelosuppression with increasing age in patients with oesophageal cancer treated by chemoradiotherapy. Eur. J. Cancer 1999, 35, 921-927. [CrossRef]

80. Port, R.E.; Daniel, B.; Ding, R.W.; Herrmann, R. Relative importance of dose, body surface area, sex, and age for 5-fluorouracil clearance. Oncology 1991, 48, 277-281. [CrossRef] [PubMed]

81. Mueller, F.; Büchel, B.; Köberle, D.; Schürch, S.; Pfister, B.; Krähenbühl, S.; Froehlich, T.K.; Largiader, C.R.; Joerger, M. Gender-specific elimination of continuous-infusional 5-fluorouracil in patients with gastrointestinal malignancies: Results from a prospective population pharmacokinetic study. Cancer Chemother. Pharmacol. 2013, 71, 361-370. [CrossRef] [PubMed]

82. Milano, G.; Etienne, M.C.; Cassuto-Viguier, E.; Thyss, A.; Santini, J.; Frenay, M.; Renee, N.; Schneider, M.; Demard, F. Influence of sex and age on fluorouracil clearance. J. Clin. Oncol. 1992, 10, 1171-1175. [PubMed]

83. Duffour, J.; Roca, L.; Bressolle, F.; Abderrahim, A.G.; Poujol, S.; Pinguet, F.; Ychou, M. Clinical impact of intesified 5-Fluorouracil-based chemotherapy using a prospective pharmacokinetically-guided dosing approach: Comparative study in elderly and non-elderly patients with metastatic colorectal cancer. J. Chemother. 2010, 22, 179-185. [CrossRef] [PubMed]

84. Medicines and Healthcare products Regulatory Agency. Public Assessment Report: Fluorouracil; Medicines and Healthcare products Regulatory Agency: London, UK, 2014.

85. Seymour, M.T.; Thompson, L.C.; Wasan, H.S.; Middleton, G.; Brewster, A.E.; Shepherd, S.F.; O’Mahony, M.S.; Maughan, T.S.; Parmar, M.; Langley, R.E. Chemotherapy options in elderly and frail patients with metastatic colorectal cancer (MRC FOCUS2): An open-label, randomised factorial trial. Lancet 2011, 377, 1749-1759. [CrossRef]

86. Kim, Y.J.; Lee, W.J.; Woo, S.M.; Kim, T.H.; Han, S.S.; Kim, B.H.; Moon, S.H.; Kim, S.S.; Koh, Y.H.; Park, S.J.; et al. Comparison of capecitabine and 5-fluorouracil in chemoradiotherapy for locally advanced pancreatic cancer. Radiat. Oncol. 2013, 8, 160. [CrossRef] [PubMed]

87. Chang, H.J.; Lee, K.W.; Kim, J.H.; Bang, S.M.; Kim, Y.J.; Kim, D.W.; Kang, S.B.; Lee, J.S. Adjuvant capecitabine chemotherapy using a tailored-dose strategy in elderly patients with colon cancer. Ann. Oncol. 2012, 23, 911-918. [CrossRef] [PubMed] 
88. Twelves, C.; Scheithauer, W.; Mckendrick, J.; Seitz, J.F.; van Hazel, G.; Wong, A.; Díaz-Rubio, E.; Gilberg, F.; Cassidy, J. Capecitabine versus 5-fluorouracil/folinic acid as adjuvant therapy for stage III colon cancer: Final results from the X-ACT trial with analysis by age and preliminary evidence of a pharmacodynamic marker of efficacy. Ann. Oncol. 2012, 23, 1190-1197. [CrossRef] [PubMed]

89. Bajetta, E.; Procopio, G.; Celio, L.; Gattinoni, L.; Della Torre, S.; Mariani, L.; Catena, L.; Ricotta, R.; Longarini, R.; Zilembo, N.; Buzzoni, R. Safety and efficacy of two different doses of capecitabine in the treatment of advanced breast cancer in older women. J. Clin. Oncol. 2005, 23, 2155-2161. [CrossRef] [PubMed]

90. Cunningham, D.; Lang, I.; Marcuello, E.; Lorusso, V.; Ocvirk, J.; Shin, D.B.; Jonker, D.; Osborne, S.; Andre, N.; Waterkamp, D.; Saunders, M.P. Bevacizumab plus capecitabine versus capecitabine alone in elderly patients with previously untreated metastatic colorectal cancer (AVEX): An open-label, randomised phase 3 trial. Lancet Oncol. 2013, 14, 1077-1085. [CrossRef]

91. Twelves, C.; Wong, A.; Nowacki, M.P.; Abt, M.; Burris, H.; Carrato, A.; Cassidy, J.; Cervantes, A.; Fagerberg, J.; Georgoulias, V.; et al. Capecitabine as adjuvant treatment for stage III colon cancer. N. Engl. J. Med. 2005, 352, 2696-2704. [CrossRef] [PubMed]

92. Blum, J.L.; Dieras, V.; lo Russo, P.M.; Horton, J.; Rutman, O.; Buzdar, A.; Osterwalder, B. Multicenter, Phase II study of capecitabine in taxane-pretreated metastatic breast carcinoma patients. Cancer 2001, 92, 1759-1768. [CrossRef]

93. Fumoleau, P.; Largillier, R.; Clippe, C.; Dièras, V.; Orfeuvre, H.; Lesimple, T.; Culine, S.; Audhuy, B.; Serin, D.; Curé, H.; et al. Multicentre, phase II study evaluating capecitabine monotherapy in patients with anthracycline- and taxane-pretreated metastatic breast cancer. Eur. J. Cancer 2004, 40, 536-542. [CrossRef] [PubMed]

94. He, Y.; Liu, P.; Zhang, Y.; Deng, X.; Meng, W.; Wei, M.; Yang, T.; Wang, Z.; Qiu, M. Low-dose capecitabine adjuvant chemotherapy in elderly stage II/III colorectal cancer patients (LC-ACEC): Study protocol for a randomized controlled trial. Trials 2015, 16, 238. [CrossRef] [PubMed]

95. Food and Drug Administration. Medical Review: Xeloda (Capecitabine); FDA: Rockville, MD, USA, 1998.

96. Food and Drug Administration. Xeloda (Capecitbine), NDA 020896, 2015.

97. Gieschke, R.; Burger, H.U.; Reigner, B.; Blesch, K.S.; Steimer, J.L. Population pharmacokinetics and concentration-effect relationships of capecitabine metabolites in colorectal cancer patients. Br. J. Clin. Pharmacol. 2003, 55, 252-263. [CrossRef] [PubMed]

98. Cassidy, J.; Twelves, C.; Cameron, D.; Steward, W.; O’Byne, K.; Jodrell, D.; Banken, L.; Goggin, T.; Jones, D.; Roos, B.; et al. Bioequivalence of two tablet formulations of capecitabine and exploration of age, gender, body surface area, and creatinine clearance as factors influencing systemic exposure in cancer patients. Cancer Chemother. Pharmacol. 1999, 44, 453-460. [CrossRef] [PubMed]

99. Gieschke, R.; Reigner, B.; Blesch, K.S.; Steimer, J.L. Population pharmacokinetic analysis of the major metabolites of capecitabine. J. Pharmacokinet. Pharmacodyn. 2002, 29, 25-47. [CrossRef] [PubMed]

100. Fischel, J.L.; Formento, P.; Ciccolini, J.; Etienne-Grimaldi, M.C.; Milano, G. Lack of contribution of dihydrofluorouracil and alpha-fluoro-beta-alanine to the cytotoxicity of 5'-deoxy-5-fluorouridine on human keratinocytes. Anticancer Drugs 2004, 15, 969-974. [CrossRef] [PubMed]

101. Daher Abdi, Z.; Lavau-Denes, S.; Prémaud, A.; Urien, S.; Sauvage, F.L.; Martin, J.; Leobon, S.; Marquet, P.; Tubiana-Mathieu, N.; Rousseau, A. Pharmacokinetics and exposure-effect relationships of capecitabine in elderly patients with breast or colorectal cancer. Cancer Chemother. Pharmacol. 2014, 73, 1285-1293. [CrossRef] [PubMed]

102. Louie, S.G.; Ely, B.; Lenz, H.J.; Albain, K.S.; Gotay, C.; Coleman, D.; Raghavan, D.; Shields, A.F.; Gold, P.J.; Blanke, C.D. Higher capecitabine AUC in elderly patients with advanced colorectal cancer (SWOGS0030). Br. J. Cancer 2013, 109, 1744-1749. [CrossRef] [PubMed]

103. European Medicines Agency. Xeloda (Capecitabine); European Medicines Agency: London, UK, 2014.

104. DRUGDEX ${ }^{\circledR}$. Carboplatin; Truven Health Analytics: Thomson Micromedex, Greenwood Village, CO, USA, 2015.

105. Ainsworth, N.L.; Marshall, A.; Hatcher, H.; Whitehead, L.; Whitfield, G.A.; Earl, H.M. Evaluation of glomerular filtration rate estimation by Cockcroft-Gault, Jelliffe, Wright and Modification of Diet in Renal Disease (MDRD) formulae in oncology patients. Ann. Oncol. 2012, 23, 1845-1853. [CrossRef] [PubMed]

106. Food and Drug Administration. Paraplatin (Carboplatin), NDA 020452, 2004. 
107. Merino-Sanjuán, M.; Monteiro, J.F.; Porta-Oltra, B.; Maestu, I.; Almenar, D.; Jiménez-Torres, N.V. Effect of age on systemic exposure and haematological toxicity of carboplatin in advanced non-small cell lung cancer patients. Basic Clin. Pharmacol. Toxicol. 2011, 109, 457-464. [CrossRef] [PubMed]

108. DRUGDEX ${ }^{\circledR}$. Cisplatin; Truven Health Analytics: Thomson Micromedex, Greenwood Village, CO, USA, 2015.

109. Himmelstein, K.J.; Patton, T.F.; Belt, R.J.; Taylor, S.; Repta, A.J.; Sternson, L.A. Clinical kinetics on intact cisplatin and some related species. Clin. Pharmacol. Ther. 1981, 29, 658-664. [CrossRef] [PubMed]

110. CBG-MEB. SmPC Platinol; CBG-MEB: Utrecht, The Netherlands, 2011.

111. Food and Drug Administration. Platinol (Cisplatin), NDA 018057. 2015.

112. Medicines and Healthcare products Regulatory Agency. Public Assessment Report: Platinol (Cisplatin); Medicines and Healthcare products Regulatory Agency: London, UK, 2010.

113. Reece, P.A.; Stafford, I.; Russell, J.; Khan, M.; Gill, P.G. Creatinine clearance as a predictor of ultrafilterable platinum disposition in cancer patients treated with cisplatin: Relationship between peak ultrafilterable platinum plasma levels and nephrotoxicity. J. Clin. Oncol. 1987, 5, 304-309. [PubMed]

114. Yamamoto, N.; Tamura, T.; Maeda, M.; Ando, M.; Shinkai, T.; Eguchi, K.; Ohe, Y.; Oshita, F.; Shiraishi, J.; Katsumata, N. The influence of ageing on cisplatin pharmacokinetics in lung cancer patients with normal organ function. Cancer Chemother. Pharmacol. 1995, 36, 102-106. [CrossRef] [PubMed]

115. Thyss, A.; Saudes, L.; Otto, J.; Creisson, A.; Gaspard, M.H.; Dassonville, O.; Schneider, M. Renal tolerance of cisplatin in patients more than 80 years old. J. Clin. Oncol. 1994, 12, 2121-2125. [PubMed]

116. Lichtman, S.M.; Buchholtz, M.; Marino, J.; Schulman, P.; Allen, S.L.; Weiselberg, L.; Budman, D.; DeMarco, L.; Schuster, M.; Lovecchio, J. Use of cisplatin for elderly patients. Age Ageing 1992, 21, 202-204. [CrossRef] [PubMed]

117. Cubillo, A.; Cornide, M.; López, J.L.; Molina, R.; Feliu, J.; Espinosa, E.; Zamora, P.; de Castro, J.; Ordoñez, A.; González Barón, M. Renal tolerance to cisplatin in patients 70 years and older. Am. J. Clin. Oncol. 2001, 24, 192-197. [CrossRef] [PubMed]

118. Piccart-Gebhart, M.J.; Procter, M.; Leyland-Jones, B.; Goldhirsch, A.; Untch, M.; Smith, I.; Gianni, L.; Baselga, J.; Bell, R.; Jackisch, C.; et al. Trastuzumab after adjuvant chemotherapy in HER2-positive breast cancer. N. Engl. J. Med. 2005, 353, 1659-1672. [CrossRef] [PubMed]

119. Seidman, A.D.; Berry, D.; Cirrincione, C.; Harris, L.; Muss, H.; Marcom, P.K.; Gipson, G.; Burstein, H.; Lake, D.; Shapiro, C.L.; et al. Randomized phase III trial of weekly compared with every-3-weeks paclitaxel for metastatic breast cancer, with trastuzumab for all HER-2 overexpressors and random assignment to trastuzumab or not in HER-2 nonoverexpressors: Final results of Cancer and Leukemia Group B Protocol 9840. J. Clin. Oncol. 2008, 26, 1642-49. [PubMed]

120. Van Hasselt, J.G.C.; Boekhout, A.H.; Beijnen, J.H.; Schellens, J.H.M.; Huitema, A.D.R. Population pharmacokinetic-pharmacodynamic analysis of trastuzumab-associated cardiotoxicity. Clin. Pharmacol. Ther. 2012, 29, 3499-511. [CrossRef] [PubMed]

121. Food and Drug Administration. Kadcyla (Ado-Trastuzumab Emtansine), BLA 125427; FDA: Rockville, MD, USA, 2015.

122. Food and Drug Administration. Drug Approvals: Kadcyla (Ado-Trastuzumab Emtansine); FDA: Rockville, MD, USA, 2013.

123. European Medicines Agency. Committee for Medicinal Products for Human Use. In Summary of Opinion: Kadcyla (Trastuzumab Emtansine); European Medicines Agency: London, UK, 2013.

124. Lu, D.; Joshi, A.; Wang, B.; Olsen, S.; Yi, J.H.; Krop, I.E.; Burris, H.A.; Girish, S. An integrated multiple-analyte pharmacokinetic model to characterize trastuzumab emtansine (T-DM1) clearance pathways and to evaluate reduced pharmacokinetic sampling in patients with HER2-positive metastatic breast cancer. Clin. Pharmacokinet. 2013, 52, 657-672. [CrossRef] [PubMed]

125. Gupta, M.; LoRusso, P.M.; Wang, B.; Yi, J.H.; Burris, H.A.; Beeram, M.; Modi, S.; Chu, Y.W.; Agresta, S.; Klencke, B.; et al. Clinical Implications of Pathophysiological and Demographic Covariates on the Population Pharmacokinetics of Trastuzumab Emtansine, a HER2-Targeted Antibody-Drug Conjugate, in Patients With HER2-Positive Metastatic Breast Cancer. J. Clin. Pharmacol. 2012, 52, 691-703. [CrossRef] [PubMed]

126. Lu, D.; Girish, S.; Gao, Y.; Wang, B.; Yi, J.H.; Guardino, E.; Samant, M.; Cobleigh, M.; Rimawi, M.; Conte, P.; et al. Population pharmacokinetics of trastuzumab emtansine (T-DM1), a HER2-targeted antibody-drug conjugate, in patients with HER2-positive metastatic breast cancer: Clinical implications of the effect of covariates. Cancer Chemother. Pharmacol. 2014, 399-410. [CrossRef] [PubMed] 
127. Dubbelman, A.; Rosing, H.; Jansen, R.S.; Mergui-roelvink, M.; Huitema, A.D.R.; Koetz, B.; Lymboura, M.; Reyderman, L.; Lopez-anaya, A.; Schellens, J.H.M.; et al. Mass Balance Study of [ 14 C ] Eribulin in Patients with Advanced Solid Tumors. Drug Metab. Dispos. 2012, 40, 313-321. [CrossRef] [PubMed]

128. Food and Drug Administration. Halaven (Eribulin Mesylate), NDA 201532, 2014.

129. European Medicines Agency. Halaven (Erybulin Mesylate); European Medicines Agency: London, UK, 2015.

130. Food and Drug Administration, Center for Drug Evaluation and Research. Clinical Pharmacology and Biopharmaceutics Review(s): Halaven (Erybulin Mesylate); FDA: Rockville, MD, USA, 2010.

131. DRUGDEX ${ }^{\circledR}$. Everolimus; Truven Health Analytics: Thomson Micromedex, Greenwood Village, CO, USA, 2015.

132. Food and Drug Administration. Afinitor (Everolimus), NDA 022334, 2015.

133. Motzer, R.J.; Escudier, B.; Oudard, S.; Hutson, T.E.; Porta, C.; Bracarda, S.; Grünwald, V.; Thompson, J.A.; Figlin, R.A.; et al. Efficacy of everolimus in advanced renal cell carcinoma: A double-blind, randomised, placebo-controlled phase III trial. Lancet 2008, 372, 449-456. [CrossRef]

134. Food and Drug Administration, Center for Drug Evaluation and Research. Clinical Pharmacology and Biopharmaceutics Review(s): AFINITOR (everolimus); FDA: Rockville, MD, USA, 2009.

135. Xu, B.; Wu, Y.; Shen, L.; Ye, D.; Jappe, A.; Cherfi, A.; Wang, H.; Yuan, R. Two-dose-level confirmatory study of the pharmacokinetics and tolerability of everolimus in Chinese patients with advanced solid tumors. J. Hematol. Oncol. 2011, 4, 3. [CrossRef] [PubMed]

136. DRUGDEX ${ }^{\circledR}$. Lapatinib; Truven Health Analytics: Thomson Micromedex, Greenwood Village, CO, USA, 2015.

137. Food and Drug Administration. Tykerb (Lapatinib Ditosylate), NDA 022059, 2015.

138. Scheffler, M.; di Gion, P.; Doroshyenko, O.; Wolf, J.; Fuhr, U. Clinical pharmacokinetics of tyosine kinase inhibitors. Clin. Pharmacokinet. 2011, 50, 371-403. [CrossRef] [PubMed]

139. Food and Drug Administration, Center for Drug Evaluation and Research. Clinical Pharmacology and Biopharmaceutics Review(s): Tykerb (Lapatinib Ditosylate); FDA: Rockville, MD, USA, 2007.

140. European Medicines Agency. Tyverb (Lapatinib Ditosylate Monohydrate); European Medicines Agency: London, UK, 2015.

141. Di Gion, P.; Kanefendt, F.; Lindauer, A.; Scheffler, M.; Doroshyenko, O.; Fuhr, U.; Wolf, J.; Jaehde, U. Clinical pharmacokinetics of tyosine kinase inhibitors: Focus on pyimidines, pyidines and pyroles. Clin. Pharmacokinet. 2011, 50, 551-603. [CrossRef] [PubMed]

142. Joerger, M. Covariate pharmacokinetic model building in oncology and its potential clinical relevance. AAPS J. 2012, 14, 119-132. [CrossRef] [PubMed]

143. Giordano, S.H.; Temin, S.; Kirshner, J.J.; Chandarlapaty, S.; Crews, J.R.; Davidson, N.E.; Esteva, F.J.; Gonzalez-Angulo, A.M.; Krop, I.; Levinson, J.; et al. Systemic Therapy for Patients With Advanced Human Epidermal Growth Factor Receptor 2-Positive Breast Cancer: American Society of Clinical Oncology Clinical Practice Guideline. J. Clin. Oncol. 2014, 32, 1-23. [CrossRef] [PubMed]

144. National Institute for Health and Care Excellence. Early and Locally Advanced Breast Cancer (Update): Diagnosis and Treatment; National Institute for Health and Care Excellence: London, UK, 2014.

145. National Institute for Health and Care Excellence. Advanced Breast Cancer (Update): Diagnosis and Treatment; National Institute for Health and Care Excellence: London, UK, 2014.

146. Partridge, A.H.; Rumble, R.B.; Carey, L.A.; Come, S.E.; Davidson, N.E.; di Leo, A.; Gralow, J.; Hortobagyi, G.N.; Moy, B.; Yee, D.; et al. Chemotherapy and Targeted Therapy for Women With Human Epidermal Growth Factor Receptor 2-Negative (or unknown) Advanced Breast Cancer: American Society of Clinical Oncology Clinical Practice Guideline. J. Clin. Oncol. 2014, 32, 3307-3329. [CrossRef] [PubMed]

147. Biganzoli, L.; Wildiers, H.; Oakman, C.; Marotti, L.; Loibl, S.; Kunkler, I.; Reed, M.; Ciatto, S.; Voogd, A.C.; Brain, E.; et al. Management of elderly patients with breast cancer: Updated recommendations of the International Society of Geriatric Oncology (SIOG) and European Society of Breast Cancer Specialists (EUSOMA). Lancet Oncol. 2012, 13, e148-e160. [CrossRef]

148. Comprehensive Cancer Centre the Netherlands (IKNL). Guideline: Breast Cancer (Draft); Comprehensive Cancer Centre the Netherlands (IKNL): Amsterdam, The Netherlands, 2015.

149. Balducci, L.; Colloca, G.; Cesari, M.; Gambassi, G. Assessment and treatment of elderly patients with cancer. Surg. Oncol. 2010, 19, 117-123. [CrossRef] [PubMed]

150. Hamaker, M.E.; Jonker, J.M.; de Rooij, S.E.; Vos, A.G.; Smorenburg, C.H.; van Munster, B.C. Frailty screening methods for predicting outcome of a comprehensive geriatric assessment in elderly patients with cancer: A systematic review. Lancet Oncol. 2012, 13, e437-e444. [CrossRef] 
151. Mathoulin-Pélissier, S.; Bellera, C.; Rainfray, M.; Soubeyan, P. Screening methods for geriatric frailty. Lancet Oncol. 2013, 14, e1-e2. [CrossRef]

152. Aaldriks, A.A.; Maartense, E.; Nortier, H.J.W.R.; van der Geest, L.G.M.; le Cessie, S.; Tanis, B.C.; Portielje, J.E.A.; Ypma, P.; Giltay, E.J. Prognostic factors for the feasibility of chemotherapy and the Geriatric Prognostic Index (GPI) as risk profile for mortality before chemotherapy in the elderly. Acta Oncol. 2016, 55, 15-23. [PubMed]

153. Clegg, A.; Young, J.; Iliffe, S.; Rikkert, M.O.; Rockwood, K. Frailty in elderly people. Lancet 2013, 381, $752-762$. [CrossRef]

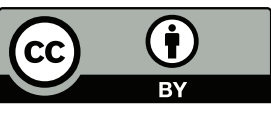

(C) 2016 by the authors; licensee MDPI, Basel, Switzerland. This article is an open access article distributed under the terms and conditions of the Creative Commons by Attribution (CC-BY) license (http://creativecommons.org/licenses/by/4.0/). 